\title{
ZEOLITE AND ACTIVATED CARBON COMBINED WITH BIOLOGICAL TREATMENT FOR METALS REMOVAL FROM MIXTURES OF LANDFILL LEACHATE AND DOMESTIC WASTEWATER
}

\author{
MOJIRI A. ${ }^{1, *}$ \\ AZIZ H.A. ${ }^{2}$ \\ ZIYANG L. ${ }^{1}$ \\ NANWEN Z. ${ }^{1}$ \\ TAJUDDIN R.M. ${ }^{3}$ \\ QARANI AZIZ S. ${ }^{4}$ \\ DONGDONG G. ${ }^{1}$
}

\author{
${ }^{1}$ School of Environmental Science and Engineering \\ Shanghai Jiao Tong University, Shanghai, China \\ ${ }^{2}$ School of Civil Engineering, Universiti Sains Malaysia \\ Nibong Tebal 14300, Penang, Malaysia \\ ${ }^{3}$ Faculty of Civil Engineering, Universiti Technology Mara (UiTM) \\ Shah Alam 40450, Selangor Darul Ehsan, Malaysia \\ ${ }^{4}$ Department of Civil Engineering, College of Engineering \\ Salahaddin University-Erbil, Iraq
}

Received: 07/08/2015

Accepted: 01/10/2015

*to whom all correspondence should be addressed:

Available online: 07/10/2015

\begin{abstract}
Current study was carried out to investigate the heavy metals removal from landfill leachate and urban wastewater by powdered activated carbon and powdered zeolite augmented SBR technique. The research was carried out in six $2000 \mathrm{~mL}$ breakers (working size was $1200 \mathrm{ml}$ ). The reactors were parted into 2 groups covering 3 for activated carbon augmented SBRs (PAC-SBR), and 3 for powdered zeolite augmented SBRs (PZE-SBR). The response surface methodology (RSM) and the central composite design (CCD) were employed to explain the most advantageous settings of the independent variables (aeration rate $\left(\left(\mathrm{min}^{-1}\right)\right.$, reaction time $(\mathrm{h})$, and leachate-to-wastewater mixing ration (\%; v/v) and their resopnses (dependent variables including $\mathrm{Fe}, \mathrm{Mn}, \mathrm{Ni}$ and $\mathrm{Cd}$ ). The results indicated that the PZE-SBR showed higher performance in removal efficiencies while compared to PAC-SBR. At the optimum conditions of contact time $(13.83 \mathrm{~h})$, aeration rate $\left(2.81 \mathrm{I} \mathrm{min}^{-1}\right)$ and leachate to domestic wastewater proportion $(20.00 \%)$ for the PZE-SBR, the removal efficiencies for $\mathrm{Fe}, \mathrm{Mn}, \mathrm{Ni}$, and $\mathrm{Cd}$ were $65.65 \%, 61.56,63.41 \%$, and $60.44 \%$, respectively.
\end{abstract}

Keywords: Activated carbon, Heavy Metals, Landfill Leachate, Sequencing Batch Reactor, Zeolite

\section{Introduction}

Sanitary landfills are the most prevalent way of solid waste treatment in most countries. Although this type of solid waste treatment provides some benefits, it has a disadvantage, including, the production of leachate. At present, approximately 230 landfills are located in Malaysia, most of which are old dumping grounds and do not have systems for environmental treatment. The leachate is released directly into water resources without any treatment and threatens neighboring ecosystem, particularly in places where landfills are situated upstream of the water intake (Aziz et al., 2011a). Landfill leachate is a type of wastewater that has significant environmental impacts because of its high-contaminant concentrations. Urban landfill leachates have contaminants that may be divided into four vital groups: dissolved organic 
matters; inorganic compounds such as calcium, potassium, sodium, ammonium, magnesium, sulphates, and chlorides; heavy metals such as lead, nickel, copper, cadmium, chromium and zinc; xenobiotic organic materials (Aziz et al., 2011b). Leachate is created when water carrying some forms of pollutants penetrates through the waste in a landfill (Foul et al., 2009). Heavy-metal pollution is a global problem, although the severity and levels of contamination differ from place to place. Common heavy metals include cadmium, lead, nickel, cobalt, zinc, and chromium (Mojiri, 2011). Heavy metals are the unique class of toxicants because they cannot be fragmented down to non-toxic forms (Waoo et al., 2014). Literature states that not more than $10 \%$ of the metals in dumpsite leachate are free metal ions (Chaari et al., 2011).

Methods for removing metals in wastewater include biological treatments, ion exchange, solvent extraction, chemical precipitation, and reverse osmosis or adsorption (Mohan and Gandhimathi, 2009). Zeolites are the most common and generally available natural ion exchangers, which has an aluminosilicate molecular structure with weak cationic bonding sites (Guisnet and Gilson, 2002). Mojiri (2011) stated that zeolite has displayed a reasonable ability to adsorb metals (copper, cadmium, lead, and zinc), and this property can be suitable for removing toxicants. Activated carbon (AC) is considered one of the best effective adsorbents, particularly for substances containing refractory organic compounds that resist biodegradation and persist in the environment. Generally, the using of AC adsorption is helpful for the removal of non-biodegradable compounds in landfill leachate (Blaney et al., 2007). Recently, many studies have focused on metal removal in wastewater and landfill leachate by using different methods (Guisnet and Gilson, 2002; Blaney et al., 2007; Mohan and Gandhimathi, 2009; Chaari et al., 2011).

Also in literature, researchers have suggested the co-treatment of landfill leachates and wastewater because of some reasons: (1) Landfill leachate treatment using biological methods is difficult because of the high COD/BOD ratio, high ammonium content, and the presence of heavy metal ions (Nesaj et al., 2007).; (2) The co-treatment process has been preferred because of low maintenance and low operating costs (Abbas et al., 2009).

The objectives of this research are as follows: (1) study the performance of SBR with powdered zeolite (PZE-SBR) and powdered AC (PAC-SBR) on the removal of cadmium, iron, manganese, and nickel from Sungai Petani Landfill leachates and household wastewater from the Bayan Baru Wastewater Treatment Plant in Malaysia; (2) compare the performance of PZE-SBR and PAC-SBR in removing heavy metals from landfill leachate and domestic wastewater.

\section{Materials and methods}

\subsection{Landfill Leachate Sampling}

Leachate samples were collected from the Sungai Petani landfill site from June 2012 to March 2013. The landfill site (geographical coordinates, $05^{\circ} 43^{\prime} \mathrm{N}$ and $100^{\circ} 29^{\prime} \mathrm{E}$ ) is located in Kedah, Malaysia. The landfill received nearly 350-400 tons of solid waste daily; it was measured by using Weight Bridge. This open dumping site has been actively applied since 1990. The total landfill area of Sungai Petani is 11.24 ha. The leachates remain in the collection pond depending on retention time, and then they are discharged directly into the environment with no treatment. After collecting the samples, they were directly carried to the laboratory and kept in a cold room at $4{ }^{\circ} \mathrm{C}$ so as to minimize biological and chemical reactions (Aziz et al., 2011b). The characteristics of the samples are given in Table 1. To determine the risks of the leachates to the environment, the obtained parameter values were compared against the 2009 Regulations of the Malaysia Environmental Quality Act of 1974 (2009).

\subsection{Domestic Wastewater and Activated Sludge Sampling}

The activated sludge and municipal wastewater were gathered from the Bayan Baru wastewater treatment plant in Penang, Malaysia. Table 1 shows the characteristics of the activated sludge and wastewater. 


\subsection{Reactors characteristics}

Six $2000 \mathrm{ml}$ beakers were used throughout the study; each of them had a working volume of $1200 \mathrm{ml}$, with an inner diameter of $113 \mathrm{~mm}$, and a height of $200 \mathrm{~mm}$. A magnetic stirrer was employed for mixing in the bottom of reactors. The experiments were carried out at room temperature, and an air pump (YASUNAGA, Air pump INC. voltage: $240 \mathrm{~V}$, Frequency: $50 \mathrm{~Hz}$, Input power $61 \mathrm{~W}$, Model: LP-60A, Pressure: $0.012 \mathrm{MPa}$, Air volume: $60 \mathrm{I} \mathrm{min}^{-1}$, Serial No.: 08110014, Made in China) was providing the reactors with air. The air flow speed was manually regulated, using an air flow meter (Dwyer Flow meter, Model: RMA26-SSV).

Table 1. Characteristics of landfill leachate, domestic wastewater and sludge

\begin{tabular}{|c|c|c|c|c|c|}
\hline No. & Parameter & $\begin{array}{c}\text { Leachate } \\
\text { Average value }\end{array}$ & $\begin{array}{l}\text { Wastewater } \\
\text { Average value }\end{array}$ & $\begin{array}{c}\text { Activated } \\
\text { Sludge } \\
\text { Average value }\end{array}$ & $\begin{array}{c}\text { Standard } \\
\text { discharge limit }\end{array}$ \\
\hline 1 & Temperature $\left({ }^{\circ} \mathrm{C}\right)$ & 28.7 & 28.6 & 28.6 & 40 \\
\hline 2 & $\mathrm{pH}$ & 8.25 & 6.87 & 6.60 & $6-9$ \\
\hline 3 & $\mathrm{EC}\left(\mathrm{ms} \mathrm{cm}^{-1}\right)$ & 3.94 & 1.00 & 1.09 & - \\
\hline 4 & Salinity $\left(\mathrm{g} \mathrm{l}^{-1}\right)$ & 2.10 & 0.02 & 0.03 & - \\
\hline 5 & Total solids $\left(\mathrm{mg} \mathrm{l}^{-1}\right)$ & 5723 & - & 10711 & - \\
\hline 6 & Suspended solids $\left(\mathrm{mg} \mathrm{l}^{-1}\right)$ & 710 & - & 9234 & 50 \\
\hline 7 & Total Hardness $\left(\mathrm{mg} \mathrm{l}^{-1} \mathrm{CaCO}_{3}\right)$ & 1912 & - & - & - \\
\hline 8 & Colour (Pt. Co) & 1690 & 6.00 & - & 100 \\
\hline 9 & $\mathrm{BOD}_{5}\left(\mathrm{mg} \mathrm{l}^{-1}\right)$ & 269.0 & 64.2 & 87.5 & 20 \\
\hline 10 & $\operatorname{COD}\left(\mathrm{mg} \mathrm{l}^{-1}\right)$ & 1301 & 156 & 218 & 400 \\
\hline 11 & TDS (\%) & 5.72 & 1.03 & 1.44 & - \\
\hline 12 & ORP (mV) & 11.6 & - & -126.0 & - \\
\hline 13 & MLVSS/MLSS & - & - & 0.82 & \\
\hline 14 & Total iron $\left(\mathrm{mg} \mathrm{l}^{-1}\right)$ & 6.03 & 1.21 & 1.95 & 5.0 \\
\hline 15 & Total manganese $\left(\mathrm{mg} \mathrm{l}^{-1}\right)$ & 1.98 & 0.67 & 0.91 & 0.20 \\
\hline 16 & Total nickel $\left(\mathrm{mg} \mathrm{l}^{-1}\right)$ & 4.94 & 0.51 & 0.78 & 0.20 \\
\hline 17 & Total cadmium ( $\mathrm{mg} \mathrm{l}^{-1}$ ) & 2.71 & 0.39 & 0.39 & 0.01 \\
\hline
\end{tabular}

a Environmental Quality (Control of Pollution from Solid Waste Transfer Station and Landfill) Regulations 2009, under the Laws of Malaysia-Malaysia Environmental Quality Act 1974

\subsection{Sludge Acclimatization}

Based on Aziz et al., (2011b) studies, $120 \mathrm{~mL}$ (10\%) of the collected landfill leachate was mixed with about $1080 \mathrm{~mL}$ of the activated sludge (90\%). When the reaction was terminated and after settling phases, 120 $\mathrm{ml}$ of the supernatant was withdrawn. In another cycle, an additional $120 \mathrm{ml}$ of the raw leachate was added to the reactor. This procedure was sustained for at least $10 \mathrm{~d}$ so as for the system to adapt to the experimental situation. This adjusted sludge was later employed as seed in the SBRs.

\subsection{Powdered Zeolite and Powdered Activated Carbone}

In this research, powdered zeolite and powdered activated carbon of size 75-150 $\mu \mathrm{m}$ were employed as adsorbent (Aziz et al., 2011a) in the PZE-SBR and PAC-SBR. Table 2 shows the features of the zeolite and activated carbon with the autosorb (Quantachrome AS1 win ${ }^{\mathrm{tm}}$, version 2.02) testing. In the current study, zeolite was from Indonesia. 
Zeolite consist has an aluminosilicate molecular structure with weak cationic bonding sites (Mojiri, 2011) so the most elements in the zeolite are Al and Si. This structure is useful for ion exchange. Activated carbon is generally applied for adsorbtion of natural organic complexes, taste and odor, and synthetic organic chemicals in drinking water treatment (Lin et al., 2010).

Table 2. Powdered Activated Carbone and Powdered Zeolite Characteristics

\begin{tabular}{|c|c|c|c|}
\hline \multirow{2}{*}{ Parameter } & \multirow{2}{*}{ Unit } & Powdered AC & \multirow[t]{2}{*}{ Powdered Zeolite } \\
\hline & & Value & \\
\hline \multicolumn{4}{|l|}{ Surface Area Data } \\
\hline MultiPoint BET & $m^{2} g^{-1}$ & $5.857 e+02$ & $4.936 e+01$ \\
\hline Langmuir surface area & $\mathrm{m}^{2} \mathrm{~g}^{-1}$ & $9.607 e+02$ & $9.480 e+01$ \\
\hline BJH method cumulative adsorption surface area & $m^{2} g^{-1}$ & $1.832 \mathrm{e}+01$ & $6.404 e+00$ \\
\hline DH method cumulative adsorption surface area & $m^{2} g^{-1}$ & $1.938 \mathrm{e}+01$ & $6.770 e+00$ \\
\hline t-method external surface area & $m^{2} g^{-1}$ & $8.681 e+01$ & $2.420 \mathrm{e}+01$ \\
\hline t-method micropore surface area & $m^{2} g^{-1}$ & $4.989 e+02$ & $2.517 e+01$ \\
\hline DR method micropore area & $m^{2} g^{-1}$ & $9.303 e+02$ & $8.305 e+01$ \\
\hline \multicolumn{4}{|l|}{ Pore Volume Data } \\
\hline $\begin{array}{l}\text { Total pore volume for pores with Diameter less than } 4.06 \mathrm{~nm} \text { at } \mathrm{P} / \mathrm{PO}= \\
\qquad 0.501894\end{array}$ & $\mathrm{cc} \mathrm{g}^{-1}$ & $3.283 e-01$ & $2.897 e-02$ \\
\hline BJH method cumulative adsorption pore volume & $\mathrm{cc} \mathrm{g}^{-1}$ & $1.887 e-02$ & $6.639 e-02$ \\
\hline DH method cumulative adsorption pore volume & $\mathrm{cc} \mathrm{g}^{-1}$ & $1.921 \mathrm{e}-02$ & $6.756 e-02$ \\
\hline t-method micropore volume & $\mathrm{cc} \mathrm{g}^{-1}$ & $2.714 \mathrm{e}-01$ & $1.323 e-02$ \\
\hline DR method micropore volume & $\mathrm{cc} \mathrm{g}^{-1}$ & $3.306 \mathrm{e}-01$ & $2.952 \mathrm{e}-02$ \\
\hline HK method cumulative pore volume & $\mathrm{cc} \mathrm{g}^{-1}$ & $3.051 \mathrm{e}-01$ & $2.285 e-02$ \\
\hline SF method cumulative pore volume & $\mathrm{cc} \mathrm{g}^{-1}$ & $3.071 e-01$ & $2.328 \mathrm{e}-02$ \\
\hline \multicolumn{4}{|l|}{ Pore Size Data } \\
\hline Average pore Diameter & $\mathrm{nm}$ & $2.242 \mathrm{e}+00$ & $2.348+00$ \\
\hline BJH method adsorption pore Diameter (Mode DV(d)) & $\mathrm{nm}$ & $3.374 \mathrm{e}+00$ & $3.666+00$ \\
\hline DH method adsorption pore Diameter (Mode Dv(d)) & $\mathrm{nm}$ & $3.374 \mathrm{e}+00$ & $3.666 e+00$ \\
\hline DA method pore Diameter (Mode) & $\mathrm{nm}$ & $1.180 e+00$ & $1.740 \mathrm{e}+00$ \\
\hline HK method pore Diameter (Mode) & $\mathrm{nm}$ & $3.675 e+01$ & $3.675 e-01$ \\
\hline SF method pore Diameter (Mode) & $\mathrm{nm}$ & $4.532 e+01$ & $4.523 e-01$ \\
\hline
\end{tabular}

\subsection{Operation of Reactors}

The SBR phases include filling, reacting, settling, drawing and idling. In all the experiments, the duration for filling and mixing (20 min), settling (90 min), drawing, and idling (10 min) were fixed. Different aeration rates of $0.5,4$, and $7.5 \mathrm{I} \mathrm{min}^{-1}$, contact times of 2,12 , and $22 \mathrm{~h}$, and different ratio of leachate to wastewater ( 20 to $80 \%$; v/v) were applied in both methods, the PZE-SBR and PAC-SBR. The beakers were filled with $120 \mathrm{ml}(10 \%)$ of adjusted sludge and $1080 \mathrm{~mL}(90 \%)$ of domestic wastewater and Sungai Petani landfill leachate (in different ratio), with the mixing ratio of $20 \%$ to $80 \%(\mathrm{v} / \mathrm{v})$. Table 1 shows the main features of wastewater, leachate, and activated sludge.

The reactors were divided into 2 groups consisting of 3 reactors for PZE-SBR (powdered zeolite augmented SBR) and 3 for PAC-SBR (powdered activated carbon augmented SBR). Based on preliminary experiments, $3.24 \mathrm{~g}$ of PZE and PAC (i.e. PZE and PAC dosage $=3 \mathrm{~g} \mathrm{l}^{-1}$ ) were added to each reactor, the PZE-SBR and PACSBR, before aeration. The PZE and PAC which were used for adsorption pollutants in the PZE-SBR and PACSBR were pre-dried at $103-105^{\circ} \mathrm{C}$ and sized $75-150 \mu \mathrm{m}$.

The removal effectiveness of manganese ( $\mathrm{Mn}$ ), iron ( $\mathrm{Fe})$, nickel $(\mathrm{Ni})$, and cadmium ( $\mathrm{Cd}$ ) were closely observed during the experiments. Removal effectiveness was determined by measuring the target parameters before and after the treatment process. Calculation of the removal efficiency was done based on the following equation (Eq. 1):

$$
\text { Removal \% }=\frac{\left(C_{i}-C_{f}\right)}{C_{i}} \times 100
$$


where $\mathrm{Ci}$ stands for the initial and $\mathrm{Cf}$ for final concentrations of the parameters.

\subsection{Analytical Methods}

Experiments were completed consistent with the Standard Methods for the Examination of Water and Wastewater (APHA, 2005). YSI 556 MPS (YSI incorporated, USA) was applied for documenting the rates of $\mathrm{pH}$, electrical conductivity $\left(\mathrm{ms} \mathrm{cm}^{-1}\right)$, temperature $\left({ }^{\circ} \mathrm{C}\right)$, salinity $\left(\mathrm{g}^{-1}\right)$, TDS $(\%)$, and oxidation decrease potential, explicitly, ORP $(\mathrm{mV})$. The average of $\mathrm{pH}$ was around 6-6.5 which was close to the normal $\mathrm{pH}$. A spectrophotometer (DR/2800 HACH) and ICP (ICP Varian, OES 715) were applied for evaluating metals (Bashir et al., 2010; Aziz et al., 2011a; Amr, 2013; Mojiri et al., 2014).

\subsection{Experimental plan and data analysis}

The central composite design (CCD) and the response surface methodology (RSM) were applied in order to explain the nature of the response surface in the experimental design and elucidate the optimal conditions of the independent variables. CCD was launched through Design Expert Software (6.0.7). The performance of the system is labelled through equation 2 an empirical second-order polynomial model (Eq. 2.):

$$
Y=\beta_{0}+\sum_{i=1}^{k} \beta_{i} X_{i}+\sum_{i=1}^{k} \beta_{i} X_{i}^{2}+\sum_{i<j}^{k} \sum_{j}^{k} \beta_{i} X_{i} X_{j}+\ldots+e
$$

where $Y$ is the response; $X i$ and $X j$ are the variables; $\beta 0$ is a constant coefficient; $\beta j, \beta j j$, and $\beta \mathrm{ij}$ are the interaction coefficients of linear, quadratic and second-order terms, respectively; $k$ is the number of study factors; and e is the error (Mojiri et al., 2013b).

Table 3. Experimental variables and results for the PAC-SBR

\begin{tabular}{cccccccc}
\hline Run & $\begin{array}{c}\text { Aeration } \\
\text { Rate } \\
\left(\mathbf{~ m i n}^{-1}\right)\end{array}$ & $\begin{array}{c}\text { Contact } \\
\text { Time (h) }\end{array}$ & $\begin{array}{c}\text { Leachate to } \\
\text { Wastewater } \\
\text { Ratio (\%) }\end{array}$ & Fe rem. (\%) & Mn rem. (\%) & Ni rem. (\%) & Cd rem. (\%) \\
\hline 1 & 4.0 & 12 & 80 & 31.49 & 26.11 & 23.96 & 26.00 \\
\hline 2 & 7.5 & 22 & 20 & 51.13 & 49.06 & 47.21 & 48.74 \\
\hline 3 & 0.5 & 22 & 80 & 31.06 & 23.98 & 23.00 & 24.13 \\
\hline 4 & 0.5 & 22 & 20 & 52.11 & 49.27 & 47.61 & 49.94 \\
\hline 5 & 0.5 & 12 & 50 & 37.04 & 32.70 & 32.10 & 32.16 \\
\hline 6 & 0.5 & 2 & 20 & 57.91 & 51.19 & 51.09 & 51.73 \\
\hline 7 & 4.0 & 12 & 50 & 43.75 & 40.49 & 40.91 & 40.15 \\
\hline 8 & 7.5 & 12 & 50 & 39.17 & 34.94 & 36.15 & 35.17 \\
\hline 9 & 4.0 & 2 & 50 & 34.04 & 31.70 & 30.10 & 31.16 \\
\hline 10 & 4.0 & 22 & 50 & 42.42 & 37.22 & 39.16 & 39.19 \\
\hline 11 & 7.5 & 22 & 80 & 29.04 & 21.31 & 20.74 & 22.02 \\
\hline 12 & 4.0 & 12 & 50 & 43.43 & 40.13 & 39.96 & 40.14 \\
\hline 13 & 7.5 & 2 & 80 & 29.97 & 22.24 & 21.21 & 23.43 \\
\hline 14 & 4.0 & 12 & 50 & 43.06 & 39.71 & 40.93 & 40.02 \\
\hline 15 & 0.5 & 2 & 80 & 30.39 & 23.13 & 21.76 & 23.00 \\
\hline 16 & 7.5 & 2 & 20 & 46.86 & 43.24 & 41.51 & 43.63 \\
\hline 17 & 4.0 & 12 & 50 & 43.99 & 39.89 & 40.91 & 41.02 \\
\hline 18 & 4.0 & 12 & 50 & 43.75 & 39.98 & 39.88 & 40.41 \\
\hline 19 & 4.0 & 12 & 20 & 60.06 & 52.55 & 55.40 & 56.53 \\
\hline 20 & 4.0 & 12 & 50 & 43.91 & 41.82 & 40.44 & 42.00 \\
\hline
\end{tabular}

${ }^{*}$ Three replications were done during this experiment

The outcomes were finally analyzed by analysis of variance (ANOVA) in the Design Expert Software. Each of the 4 functional variables was regarded at 3 levels, low $(-1)$, central $(0)$, and high $(+1)$. In the current study, CCD and RSM were used to assess the relationship between the most significant functional variables (Mojiri et al., 2013a), explicitly, aeration rate $\left(\mathrm{min}^{-1}\right)$, reaction time (contact time, h), and 
leachate-to-wastewater mixing portion (\%; v/v) and their reactions (dependent variables) as well as improving the proper condition of functional variables to foresee the paramount value of reactions. Contact times $(2,12$, and $22 \mathrm{~h})$, aeration rates $\left(0.5,4\right.$, and $\left.7.5 \mathrm{I} \mathrm{min}^{-1}\right)$, and leachate to wastewater blending proportion (80, 50, and $20 \mathrm{v} / \mathrm{v} \%$ ) were employed with PZE-SBR and PAC-SBR. With the purpose of performing a sufficient study of the aerobic procedure, 4 dependent factors ( $\mathrm{Fe}, \mathrm{Cd}, \mathrm{Mn}$ and $\mathrm{Ni}$ ) were considered as responses (Tables 3 and 4).

Table 4. Experimental variables and results for the PZE-SBR

\begin{tabular}{|c|c|c|c|c|c|c|c|}
\hline Run & $\begin{array}{c}\text { Aeration } \\
\text { Rate } \\
\left(\mathbf{~ m i n}^{-1}\right)\end{array}$ & $\begin{array}{c}\text { Contact } \\
\text { Time (h) }\end{array}$ & $\begin{array}{c}\text { Leachate to } \\
\text { Wastewater } \\
\text { Ratio (\%) }\end{array}$ & Fe rem. (\%) & Mn rem. (\%) & Ni rem. (\%) & Cd rem. (\%) \\
\hline 1 & 4.0 & 12 & 80 & 31.96 & 32.13 & 32.17 & 30.91 \\
\hline 2 & 7.5 & 22 & 20 & 59.11 & 54.76 & 58.38 & 56.11 \\
\hline 3 & 0.5 & 22 & 80 & 31.01 & 30.72 & 30.43 & 28.89 \\
\hline 4 & 0.5 & 22 & 20 & 63.03 & 57.09 & 61.27 & 57.24 \\
\hline 5 & 0.5 & 12 & 50 & 47.18 & 41.19 & 47.83 & 44.73 \\
\hline 6 & 0.5 & 2 & 20 & 61.70 & 55.76 & 60.00 & 56.26 \\
\hline 7 & 4.0 & 12 & 50 & 52.96 & 49.13 & 50.14 & 46.81 \\
\hline 8 & 7.5 & 12 & 50 & 45.00 & 39.00 & 46.40 & 41.97 \\
\hline 9 & 4.0 & 2 & 50 & 49.19 & 42.99 & 47.13 & 44.12 \\
\hline 10 & 4.0 & 22 & 50 & 49.13 & 42.09 & 46.11 & 44.64 \\
\hline 11 & 7.5 & 22 & 80 & 29.90 & 28.74 & 25.14 & 28.04 \\
\hline 12 & 4.0 & 12 & 50 & 52.84 & 47.79 & 48.09 & 46.74 \\
\hline 13 & 7.5 & 2 & 80 & 30.02 & 27.31 & 26.19 & 27.17 \\
\hline 14 & 4.0 & 12 & 50 & 53.11 & 49.00 & 47.11 & 46.99 \\
\hline 15 & 0.5 & 2 & 80 & 31.90 & 28.94 & 27.77 & 27.99 \\
\hline 16 & 7.5 & 2 & 20 & 56.18 & 51.56 & 47.97 & 52.93 \\
\hline 17 & 4.0 & 12 & 50 & 53.44 & 48.06 & 49.01 & 47.13 \\
\hline 18 & 4.0 & 12 & 50 & 53.11 & 47.91 & 49.92 & 47.27 \\
\hline 19 & 4.0 & 12 & 20 & 65.08 & 59.93 & 63.18 & 60.41 \\
\hline 20 & 4.0 & 12 & 50 & 53.04 & 47.91 & 48.71 & 48.00 \\
\hline
\end{tabular}

*Three replications were done during this experiment

\section{Results and discussions}

As Table 1 shows, Sungai Petani leachate contained high-intensity $\mathrm{Mn}\left(1.98 \mathrm{mg}^{-1}\right)$, and high concentration of $\mathrm{Ni}\left(4.94 \mathrm{mg} \mathrm{l}^{-1}\right)$. Also, $\mathrm{Cd}$ had a high concentration $\left(2.71 \mathrm{mg} \mathrm{l}^{-1}\right)$. In addition, the concentration of pollutants exceeded the permissible limits issued by the 1974 Environmental Quality Act of Malaysia (2009). In the present study, the heavy metals removal from raw leachate of the Sungai Petani landfill and domestic wastewater was performed through PZE and PAC augmented SBR process to decrease the environmental risks caused by the SG Petani landfill leachate. The 3D surface plots of pollutants removal "Fe, $\mathrm{Mn}, \mathrm{Ni}$, and Cd" in PAC-SBR and PZE-SBR are shown in the Figures 1 and 2.

\subsection{Reactor performance}

\subsubsection{Iron removal}

Iron is present in varying concentrations in all ecosystems that they are stable and persistent environmental contaminants since they cannot be degraded or destroyed.

In PAC-SBR, 58.57\% was reached as the optimum removal of Fe at the aeration rate of $2.94 \mathrm{I} \mathrm{min} \mathrm{m}^{-1}, 10.93$ $\mathrm{h}$ contact time, and $20.00 \%$ leachate-to-wastewater proportion. In PZE-SBR, $65.11 \%$ was achieved as the optimum removal of $\mathrm{Fe}$ at the aeration proportion of $3.63 \mathrm{I} \mathrm{min}^{-1}, 13.63 \mathrm{~h}$ reaction time, and $21.14 \%$ leachate-to-wastewater ratio. 


\subsubsection{Manganese removal}

It is well known that leachates produced by water percolation through solid waste often contain high concentrations of dissolved Fe and Mn (Lebrun et al., 2007; Siegel and Siegel, 2007).

In PAC-SBR, 52.60\% was attained as the optimum removal of $\mathrm{Mn}$ effectiveness of at the aeration rate of $4.21 \mathrm{I} \mathrm{min}^{-1}, 20.84 \mathrm{~h}$ reaction time, and $20.05 \%$ leachate-to-wastewater ratio. In PZE-SBR, 60.77\% was attained as the optimum $\mathrm{Mn}$ removal effectiveness of at the aeration proportion of $2.57 \mathrm{I} \mathrm{min}^{-1}, 8.77 \mathrm{~h}$ reaction time, and $20.14 \%$ leachate to wastewater proportion.

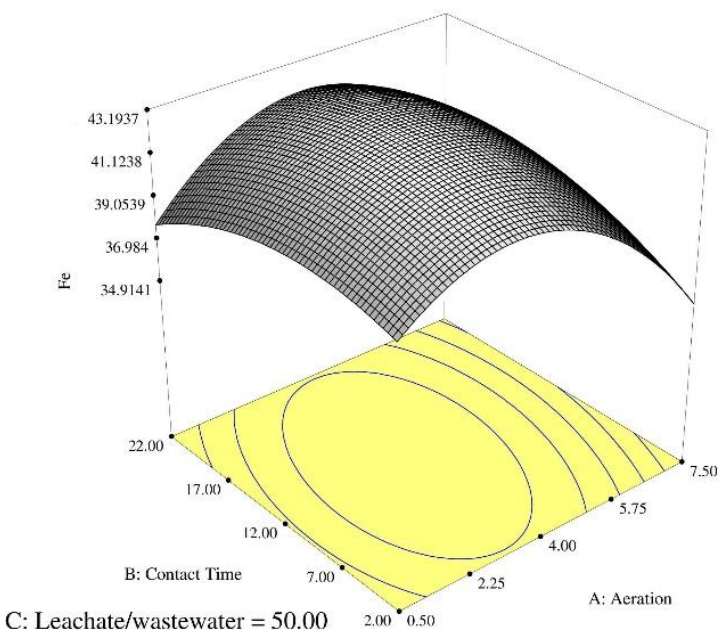

(a)

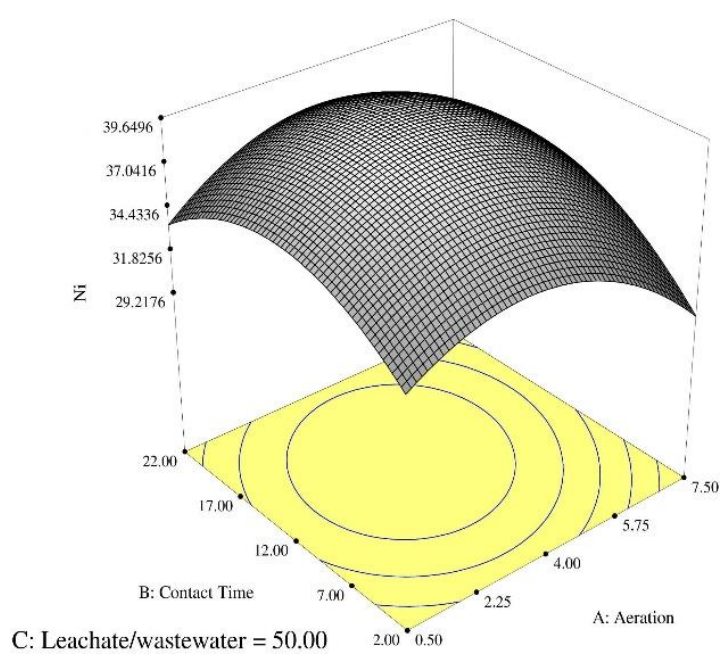

(c)

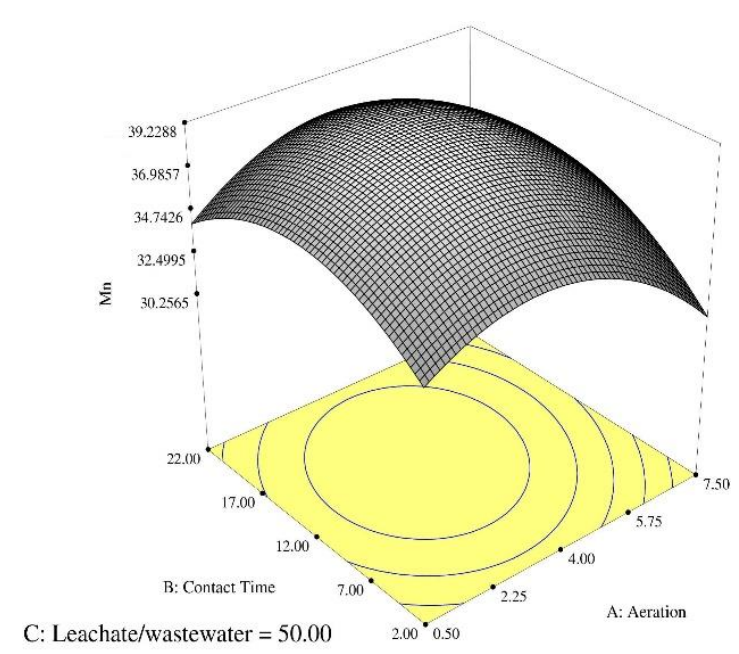

(b)

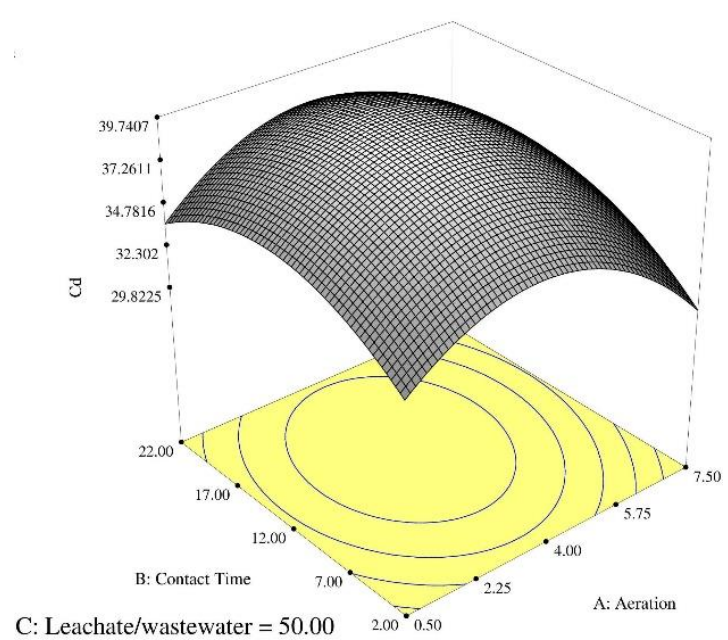

(d)

Figure 1. The 3D surface plot of (a) Fe and (b) Mn, (c) Ni and (d) Cd removal in the PAC-SBR

\subsubsection{Nickel removal}

Leachate and wastewater may enclose a huge amount of heavy metals, such as nickel, which is a nonbiodegradable toxic heavy-metal ion present in wastewater (Al-Qodah, 2006). Several materials have been applied as adsorbents to remove Ni (II), including AC, ion-exchange resins, silica, rock materials, agricultural wastes, microbial and plant derived biomass, and chitin. However, developing a low-cost, easily available, and high-adsorption material for wastewater treatment remains necessary (Varma et al., 2013). 
In PAC-SBR, the best possible Ni removal effectiveness of $54.69 \%$ was attained at the aeration proportion of $3.28 \mathrm{I} \mathrm{min}^{-1}$, contact time of $13.77 \mathrm{~h}$, and leachate-to-wastewater proportion of $20.00 \%$. In PZE-SBR, the optimum Ni removal effectiveness of $63.19 \%$ was attained at the aeration proportion of $1.61 \mathrm{I} \mathrm{min}{ }^{-1}$, contact time of $13.40 \mathrm{~h}$, and leachate-to-wastewater proportion of $21.13 \%$.

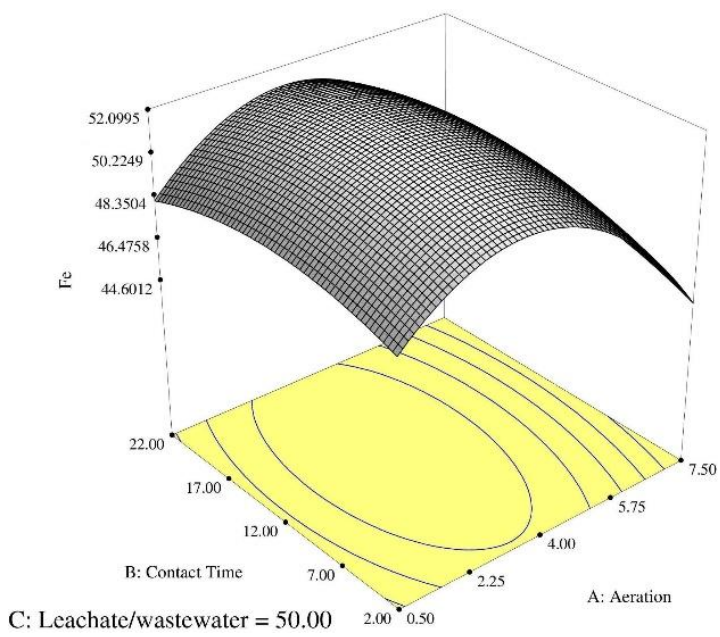

(a)

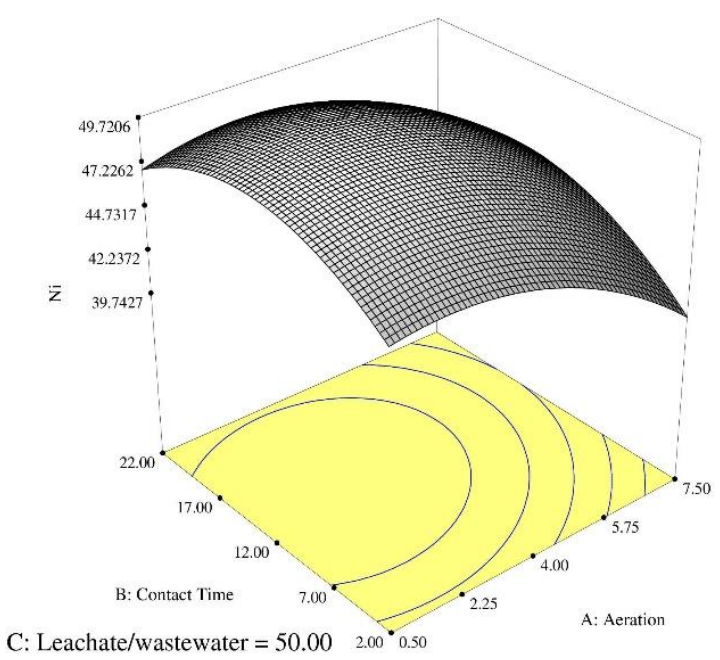

(c)

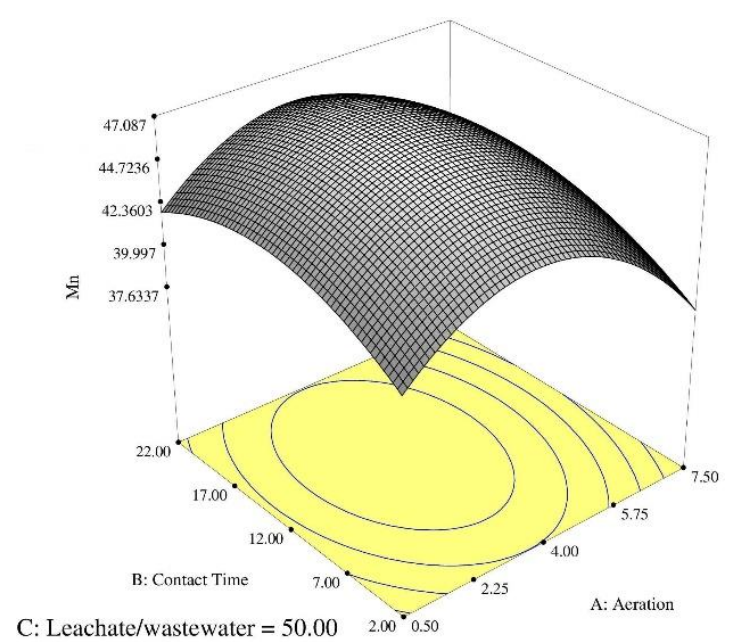

(b)

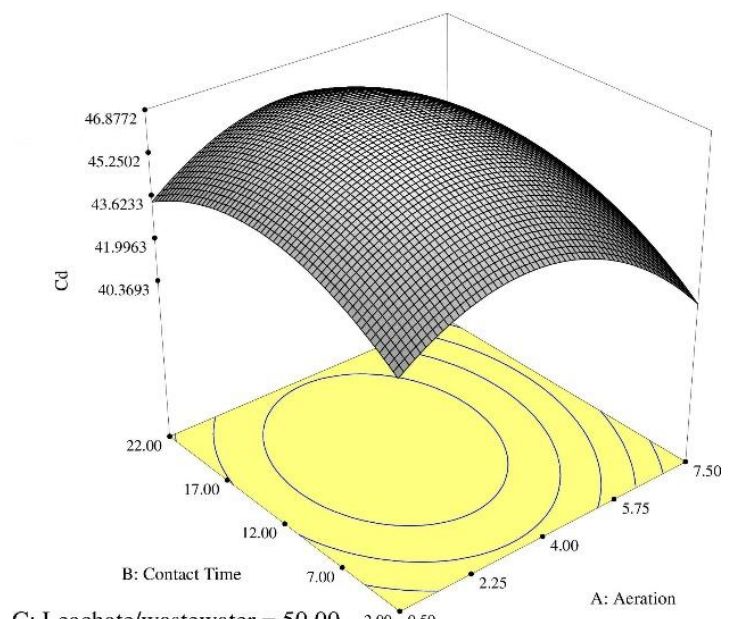

(d)

Figure 2. The 3D surface plot of (a) Fe, (b) Mn, (c) Ni and (d) Cd removal in the PZE-SBR

\subsubsection{Cadmium removal}

Cadmium is a soft, malleable, white metal that is generally used in batteries, alloys, electroplating, solar cells, plastic stabilizers, and pigments. Cadmium is a highly toxic metal and exposure to it is known to cause cancer. Cadmium is also a hazard to the environment mainly because of fossil fuel combustion (Baker et al., 2012).

In PAC-SBR, the best possible Cd removal effectiveness of $56.33 \%$ was attained at an aeration rate of $3.36 \mathrm{I} \mathrm{min}^{-1}$, reaction time of $14.50 \mathrm{~h}$, and leachate-to-wastewater proportion of $20.00 \%$. In PZE-SBR, $60.41 \%$ was achieved as the optimum removal of $\mathrm{Cd}$ at an aeration proportion of $2.76 \mathrm{I} \mathrm{min}^{-1}$, reaction time of $15.39 \mathrm{~h}$, and leachate-to-wastewater proportion of $20.03 \%$. 


\subsection{Statistical analysis and Experimental condition optimization}

A fundamental composite plan and a reaction surface method were employed to display the nature of the reaction surface in the empirical plan and clarify the best possible setting of the independent variables. CCD was launched via Design-Expert 6.0.7. Aeration rate $\left(1 \mathrm{~min}^{-1}\right)$, reaction time $(\mathrm{h})$, and leachate-towastewater combining ratio (\%; v/v) were the independent factors. Four dependent factors ( $\mathrm{Fe}, \mathrm{Mn}, \mathrm{Ni}$, and $\mathrm{Cd}$ ) were evaluated as responses (Tables 3 and 4 ).

Tables 5 illustrates the reaction values for each factor. These boundaries were selected fairly near to the attained utmost removal and viability principles of treatment sites. The improvement of the empirical settings was recognized by regarding whether the rates of $\mathrm{Fe}, \mathrm{Mn}, \mathrm{Cd}$, and $\mathrm{Ni}$ removal were higher than the randomly selected restraint values. The best possible settings were envisaged by the Design-Expert software. Further, Table 5 displays the reduced quadratic models in terms of actual factors. All models were significant at the $5 \%$ confidence level because probability values were less than 0.05 . The coefficient of determination $\left(\mathrm{R}^{2}\right)$ offered the proportion of total variation in the response predicted by the model, indicating the ratio of sum of squares due to regression to total sum of squares. $R^{2}$ values close to 1 were wanted, and a high $\mathrm{R}^{2}$ coefficient guaranteed suitable modification of the quadratic model to the experimental data. In the present study, all obtained R2 were greater than 0.95, Table 5.

Adsorption is now identified as an effective and economic way for heavy-metal wastewater treatment. The adsorption procedure proposals flexibility in design and operation and will produce high-quality treated water many cases. Furthermore, given that adsorption is sometimes reversible, adsorbents can be regenerated by the suitable deception process. AC adsorbents are widely employed in removing of contaminants (Aghamohammadi et al., 2007; Aziz et al., 2011a; 2011b; 2011c; Aziz et al., 2012; Mojiri et al., 2014). A large number of researchers are investigating the usage of AC to remove heavy metals (Fu and Wang, 2011; Aziz et al., 2011c; Mojiri et al., 2014).

Ion-exchange processes have been generally applied to remove heavy metals from wastewater because of their benefits, such as high treatment capacity, high removal effectiveness, and fast kinetics. Many researches have confirmed that zeolites display a good ion-exchange abilities for removing heavy-metal under different experimental environments (Motsi et al., 2009; Ostroski et al., 2009; Taffarel et al., 2009).

In current study, the PZE-SBR performance was more than PAC-SBR performance because zeolite could do ion exchange and also the metals can fix in the pores of it. But activated carbon cannot do ion exchange and just heavy metals can fix in the pores. In addition, based on some business websites, the zeolite price is less than activated carbon price so using zeolite is more affordable than activated carbon (http://www.alibaba.com/showroom/zeolite-price.html, http://www.alibaba.com/showroom/activatedcarbon-price.html).

Table 5. ANOVA results for response parameters

\begin{tabular}{c|c|c|c|c}
\hline SBR Type & Responses & Final equation in terms of actual factors & Prob. & $\mathbf{R}^{\mathbf{2}}$ \\
\hline \multirow{4}{*}{ PAC-SBR } & $\mathrm{Fe}$ & $69.544-0.786 \mathrm{C}-0.371 \mathrm{~A}^{2}+0.004 \mathrm{C}^{2}$ & $<0.0001$ & 0.9652 \\
\cline { 2 - 5 } & $\mathrm{Mn}$ & $58.895-0.661 \mathrm{C}-0.280 \mathrm{~A}^{2}$ & $<0.0001$ & 0.9647 \\
\cline { 2 - 5 } & $\mathrm{Ni}$ & $58.380-0.652 \mathrm{C}$ & $<0.0001$ & 0.9508 \\
\cline { 2 - 5 } & $\mathrm{Cd}$ & $61.699-0.811 \mathrm{C}-0.361 \mathrm{~A}^{2}$ & $<0.0001$ & 0.9594 \\
\hline \multirow{4}{*}{ PZE-SBR } & $\mathrm{Fe}$ & $67.032+1.823 \mathrm{~A}-0.312 \mathrm{C}-0.341 \mathrm{~A}^{2}$ & $<0.0001$ & 0.9869 \\
\cline { 2 - 5 } & $\mathrm{Mn}$ & $64.516-0.622 \mathrm{C}-0.390 \mathrm{~A}^{2}$ & $<0.0001$ & 0.9755 \\
\cline { 2 - 5 } & $\mathrm{Ni}$ & $63.568-0.296 \mathrm{C}-0.028 \mathrm{~B}^{2}$ & $<0.0001$ & 0.9830 \\
\cline { 2 - 5 } & $\mathrm{Cd}$ & $63.162+1.320 \mathrm{~A}+0.510 \mathrm{~B}-0.413 \mathrm{C}-0.229 \mathrm{~A}^{2}-$ & $<0.0001$ & 0.9965 \\
\hline
\end{tabular}

*Prob.: Probability of error; and $\mathrm{R}^{2}$ : Coefficient of determination.

**In final equations, where $A$ is Aeration rate $\left(I \mathrm{~min}^{-1}\right), B$ is contact time $(\mathrm{h})$, and $\mathrm{C}$ is leachate to wastewater mixing ration $(\% ; \mathrm{v} / \mathrm{v})$ 


\section{Conclusions}

Elimination of heavy metals from Sungai Petani landfill leachate and domestic wastewater was performed via powdered zeolite and powdered activated carbon supplemented SBR procedure. A number of pollutants in Sungai Petani landfill leachate went beyond the allowable discharge restrictions comprising $\mathrm{Fe}, \mathrm{Mn}, \mathrm{Ni}$ and $\mathrm{Cd}$. In the PAC-SBR treatment case, the obtained optimum removal levels of $\mathrm{Fe}, \mathrm{Mn}, \mathrm{Ni}$, and $\mathrm{Cd}$ were $58.47 \%, 54.32 \%, 54.68$ and $56.30 \%$, respectively. On the other hand, using the PZE-SBR treatment led to $65.65 \%, 61.56,63.41 \%$, and $60.44 \%$ removals, respectively. Thus, it can be concluded that, for heavy metals removal from landfill leachate and domestic wastewater, employing the PZE-SBR method was more effective than the application of the traditional PAC-SBR.

\section{References}

Abbas A.A., Jingsong G., Ping L.Z., Ya P.Y. and Al-Rekabi W.S. (2009), Review on landfill leachate treatments, Journal of Applied Sciences Research, 5(5), 534-545.

Aghamohammadi N., Aziz H.A., Isa M.H. and Zinatizadeh A.A. (2007), Powdered activated carbon augmented activated sludge process for treatment of semi-aerobic landfill leachate using response surface methodology, Bioresource Technology, 98, 3570-3578.

Al-Qodah Z. (2006), Biosorption of heavy metal ions from aqueous solutions by activated sludge, Desalination, 196, 164-176.

Amr S.S.S.A. (2013), Comparison and optimization of ozone - based advanced oxidation processes in the treatment of stabilized landfill leachate. PhD Thesis, Universiti Sains Malaysia.

APHA (2005), Standard Methods for the Examination of Water and Wastewater, $21^{\text {st }}$ ed., American public health association, Washington DC.

Aziz S.Q., Aziz H.A, Yusoff M.S. and Bashir M.J.K. (2011b), Landfill leachate treatment using powdered activated carbon augmented sequencing batch reactor (SBR) process: Optimization by response surface methodology, Journal of Hazardous Materials, 189, 404-413.

Aziz S.Q., Aziz H.A. and Yusoff M.S. (2011a), Optimum Process Parameters for the Treatment of Landfill Leachate using Powdered Activated Carbon Augmented Sequencing Batch Reactor (SBR) Technology, Separation Science and Technology, 46, 1-12.

Aziz, S.Q., Aziz, H.A., Yusoff M.S. and Mohajeri S. (2011c), Removal of phenols and other pollutants from different landfill leachates using powdered activated carbon supplemented SBR technology, Environmental Monitoring and Assessment, 184(10), 6147- 6158.

Aziz S.Q., Aziz H.A., Yusoff M.S., Mojiri A. and Abu Amr S. (2012), Adsorption isotherms in landfill leachate treatment using powdered activated carbon augmented sequencing batch reactor technique: Statistical analysis by response surface methodology, International Journal of Chemical Reactor Engineering, 10(1), 1542-6580.

Baker S., Ouellette M., Rodrigues M. and Suddapalli S. (2012), Brush Nickel Plating and Heavy Metal Wastewater Treatment Process Optimization, Major Qualifying Project completed in partial fulfillment Of the Bachelor of Science Degree at Worcester Polytechnic Institute, Worcester, MA.

Bashir M.J.K., Aziz H.A., Yusoff M.S. and Adlan M.N. (2010), Application of response surface methodology (RSM) for optimization of ammoniacal nitrogen removal from semi-aerobic landfill leachate using ion exchange resin, Desalination, 254, 154-161.

Blaney L.M., Cinar S. and Sen Gupta A.K. (2007), Hybrid anion exchanger for trace phosphate removal from water and wastewater, Water Research, 41, 1603-1613.

Chaari I., Medhioub M. and Jamoussi F. (2011), Use of Clay to Remove Heavy Metals from Jebel Chakir Landfill Leachate, Journal of Applied Sciences in Environmental Sanitation, 6(2), 143-148. 
Environmental Quality (Control of Pollution from Solid Waste Transfer Station and Landfill) Regulations, (2009), Under the Laws of Malaysia-Malaysia Environmental Quality Act, 1974.

Foul A.A., Aziz H.A., Isa M.H. and Hung Y.T. (2009), Primary treatment of anaerobic landfill leachate using activated carbon and limestone: batch and column studies, Inter. J. Environ. and Waste Management, 4, 282- 290.

Fu F. and Wang Q. (2011), Removal of heavy metal ions from wastewaters: A review, Journal of Environmental Managament, 92, 407-418.

Guisnet M. and Gilson J. (2002), Zeolites for cleaner technologies. London, U.K.: Imperial College Press.

Lebrun V., Kheffi A., Collart C., Peters V. and Maquinay J.C.L. (2007), Iron and Manganese Survey in Aquifers Surrounding Landfills in Wallonia (Belgium), Proceedings Sardinia 2007, Eleventh International Waste Management and Landfill Symposium S. Margherita di Pula, Cagliari, Italy; 1 - 5 October.

Li T., Chen W. and Wang L. (2010), Particle properties in granular activated carbon filter during drinking water treatment, Journal of Environmental Sciences (China), 22(5), 681-8.

Mohan S. and Gandhimathi R. (2009), Removal of heavy metal ions from municipal solid waste leachate using coal fly ash as an adsorbent, Journal of Hazardous, Materials, 169, 351-359.

Mojiri A. (2011), Review on Membrane Bioreactor, Ion Exchange and adsorption Methods for Landfill Leachate Treatment, Australian Journal of Basic and Applied Sciences, 5(12), 1365-1370.

Mojiri A., Aziz H.A., Aziz S.Q., Selamat M.R.B., Gholami A. and Aboutorab M. (2013a), Phytoremediation of Soil Contaminated with Nickel by Lepidiumsativum; Optimization by Response Surface Methodology, Global NEST Journal, 15(1), 69-75.

Mojiri A., Aziz H.A., Zahed M.A., Aziz S.Q. and Selamat M.R.B. (2013b), Phytoremediation of Heavy Metals from Urban Waste Leachate by Southern Cattail (Typha domingensis), International Journal of Scientific Research in Environmental Sciences, 1(4), 63-70.

Mojiri A., Aziz H.A., Zaman N.Q., Aziz S.Q. and Zahed M.A. (2014), Powdered ZELIAC augmented sequencing batch reactors (SBR) process for co-treatment of landfill leachate and domestic wastewater, Journal of Environmental Management, 139, 1-14.

Motsi T., Rowson N.A. and Simmons M.J.H. (2009), Adsorption of heavy metals from acid mine drainage by natural zeolite, International Journal of Mineral Processing, 92, 42-48.

Neczaj E., Kacprzak M., Lach J. and Okoniewska E. (2007), Effect of sonication on combined treatment of landfill leachate and domestic sewage in SBR reactor, Desalination, 204, 227-233

Ostroski I.C., Barros M.A.S.D, Silvab E.A., Dantas J.H., Arroyo P.A. and Lima O.C.M. (2009), A comparative study for the ion exchange of Fe(III) and $\mathrm{Zn}(\mathrm{II})$ on zeolite NaY, Journal of Hazardous Materials, 161, 1404-1412.

Siegel A. and Siegel H. (2000), Metal lons in Biological Systems: Manganese and its role in biological processes, Vol. 37, CRC Press, $816 \mathrm{p}$.

Taffarel S.R. and Rubio J. (2009), On the removal of $\mathrm{Mn}^{2+}$ ions by adsorption onto natural and activated Chilean zeolites, Minerals Engieering, 22, 336-343.

Varma S., Sarode D., Wakale S., Bhanvase B.A. and Deosarkar M.P. (2013), Removal of Nickel from Waste Water Using Graphene Nanocomposite, International Journal of Chemical and Physical Science, 2(Special Issue), 132-139.

Waoo A.A., Khare S. and Ganguly S. (2014), Comparative in-vitro Studies on Native Plant Species at Heavy Metal Polluted Soil Having Phytoremediation Potential, International Journal of Scientific Research in Environmental Sciences, 2, 49-55. 